\title{
Relationship of Parities with Benefits Knowledge of Maternal and Child (KIA) Book for Pregnant Women at Public Heath Centre 1 Gamping 1
}

\author{
${ }^{1}$ Belian Anugrah Estri * \\ Aisyiyah University, West Ringroad 63 Nogotirto Gamping Sleman 55292, Yogyakarta, Indonesia \\ ${ }^{1}$ Belianestri@unisayogya.ac.id* \\ *corresponding author \\ Submission date: 10 Juli 2020, Receipt date: 15 Juli 2020, Publication date: 1 November 2020
}

\begin{abstract}
Public awareness about pregnant women health's still a determining factor for MMR and IMR. Although there are still many factors that must be considered to deal with this problem, one of the causes of death is the ignorance of pregnant women and their families in recognizing danger signs of pregnancy, to solve this the government is trying to improve awareness and knowledge of pregnant women and their families with maternal and child health books (KIA). This study aims to to determine whether there is a relationship between parity and knowledge about the benefits of the KIA Handbook for pregnant women at Gamping 1 health center. This research is a quantitative study. The data collection method based on the time approach used is the cross section method. The sampling technique used was purposive sampling, namely taking samples according to the inclusion and exclusion criteria of 45 respondents with the Chi Square relationship test with a significance level of 95\%. Chi Squere test results show that the $p$-value is 0.020. Therefore, the p-value $>\alpha(0.05)$ means that there is a relationship between parity and the knowledge of pregnant women on the KIA Handbook at the Gamping 1 Health Center in Yogyakarta. Pregnant women are expected to continue to use and read the KIA Handbook during pregnancy in order to increase mother's knowledge.
\end{abstract}

Keywords: Parity, pregnant women, KIA book knowledge

\section{INTRODUCTION}

Indonesia needs a national achievement development with independent availability and quality human resources. Indonesia's attention to goal of health development in improving the health and nutrition status of the community throughout the life cycle, both at the individual, family and community levels (Bapennas, 2015). Public awareness about the health of pregnant women is still a determining factor for MMR and IMR. Although there are still many factors that must be considered to deal with this problem, one of the causes of death is the ignorance of pregnant women and their families in recognizing danger signs of pregnancy, to solve this the government is trying to improve awareness and knowledge of pregnant women and their families with maternal and child health books (in Indonesia known as KIA books).

The maternal mortality rate is one of the targets in the fifth SDGs development goal, which is to reduce the maternal mortality rate by $3 / 4$ from the maternal mortality rate in 1999 of 450 per 100,000 to 102 per 100,000 live births in 2015 . 
In 2015 the number of maternal deaths was 126 per 100,000 live births and increased to 182.2 per 100,000 live births in 2016. The decline in maternal mortality per 100,000 live births is still too slow to achieve the SDGs development goals (Dinkes DIY, 2017). In 2015 the coverage of KIA books in Yogyakarta City reached 100\%, however, there is no complete data regarding the use of KIA books in Yogyakarta. The use of the KIA Handbook by pregnant women has only been limited as a means of recording pregnancy, growth during posyandu and given immunizations.

The government in Indonesia made a policy, namely the Decree of the Minister of the Republic of Indonesia 284 / MENKES / SKIII / 2004 concerning the Maternal and Child Health (KIA) book, stating that the KIA book is one of the communication tools and media for education for mothers and families and the community regarding maternal and child health services including referral and package (standard) of KIA services, nutrition, immunization, and toddler development (Kemenkes, 2015). Maternal mortality can occur during pregnancy, during childbirth and during the puerperium due to a lack of knowledge to recognize the danger signs that are experienced such as excessive nausea, vomiting, bleeding, premature rupture of membranes, fever, swelling of the hands and even the face with blood pressure, height and reduced fetal movement.

Ignorance of this causes delays in dealing with danger signs in pregnancy that will seriously endanger the lives of both the mother and the fetus. In reducing MMR, the government has issued several programs and efforts, one of which is the Maternal and Child Health Book program or the KIA Handbook which has been piloted since 1994 (Depkes, 2013). The KIA book is collaboration between the Ministry of Defense and the Republic of Indonesia and the Japan International Cooperation Agency (JICA) as one of the government's efforts to reduce MMR. The KIA Handbook is a simple and effective information, education and communication tool (Destria, 2010). Based on the third competency, midwives have the authority to provide comprehensive antenatal midwifery care to optimize health during pregnancy which includes early detection, treatment.

The data on visits of pregnant women at Gamping I health center in 2018-2019 were 950 pregnant women, and the results were obtained in the last 3 months of September-November 2018 as many as 225 pregnant women, all pregnant women were given the KIA Book freely to carry with each visit and monitor their health pregnant mother. Midwife there always explained that the KIA handbook must always be taken when carrying out examinations to health workers, whether it was pregnancy checks, during childbirth, during the postpartum period, when checking babies and toddlers as well as being carried when giving immunizations to infants and toddlers. Mothers are asked to take care of the books so they are not lost or damaged and are also asked to read the KIA books at home. Based on the background above

\section{RESEARCH METHODS}

This research is a quantitative study with an analytic observational research design with a cross-sectional design. The independent variable of this study is parity and the dependent variable of this study is pregnant women knowledge about the benefits of KIA handbook. The population in the study was all pregnant women who visited the ANC at Gamping Public Health Center 1, at 3 months start from February, March, April in 2019, totaling 225 pregnant women. The sample size was taken from $20 \%$ of the population using purposive sampling as many as 45 pregnant women who conducted 
examinations at the Gamping Health Center 1 in Yogyakarta. Data collection used questionnaire technique. The data analysis technique used chi square test.

1. Univariate Analysis

\section{RESULTS AND DISCUSSION}

a. Description of Maternal Age in Pregnant Women at Gamping Health Center 1.

Table 1. Frequency distribution of maternal age among pregnant women at Gamping Health Center 1

\begin{tabular}{lcc}
\hline \multicolumn{1}{c}{ Mother's Age } & Frequency & Percentage \\
\hline At risk (<20 years and $>$ 35 years) & 7 & $15.6 \%$ \\
\hline Healthy reproduction (20-35 years) & 38 & $84.4 \%$ \\
\hline Total & 45 & $100 \%$ \\
\hline
\end{tabular}

Based on table 1, it can be seen that most of pregnant women at Gamping I Health Center were mostly in healthy reproductive age (20-35 years), namely 38 respondents or $84.4 \%$.

b. Educational overview of pregnant women at Gamping Health Center 1

Table 2. Education frequency distribution among pregnant women at Gamping Health Center 1

\begin{tabular}{|c|c|c|}
\hline Education & Frequency & Percentage \\
\hline SD & 1 & $24.4 \%$ \\
\hline Junior High School & 3 & $6.7 \%$ \\
\hline Senior High school & 31 & $68.9 \%$ \\
\hline D3 & 4 & $8.9 \%$ \\
\hline S1 & 6 & $13.3 \%$ \\
\hline Total & 45 & $100 \%$ \\
\hline
\end{tabular}

Based on table 2, it can be seen that most of pregnant women at Gamping I Health Center had at most high school education levels, namely 31 respondents or $68.9 \%$.

c. Description of parity in pregnant women at Gamping Health Center 1

Table 3. Frequency distribution of maternal age among pregnant women at Gamping Health Center 1

\begin{tabular}{lccc}
\hline & Parity & Frequency & Percentage \\
\hline Primigravida & 25 & $55.6 \%$ \\
\hline Multigravida & 20 & $44.4 \%$ \\
\hline Total & 45 & $100 \%$ \\
\hline
\end{tabular}

Based on table 3, it can be seen that most of pregnant women at Gamping Health Center 1 were mostly primigravidas, namely 25 respondents or $55.6 \%$. 
d. Knowledge description on pregnant women at Gamping Health Center 1

Table 4. Distribution of knowledge frequency among pregnant women at Gamping Health Center 1

\begin{tabular}{lccc}
\hline & Knowledge & Frequency & Percentage \\
\hline Moderate & 15 & $33.3 \%$ \\
\hline Well & 30 & $66.7 \%$ \\
\hline Total & 45 & $100 \%$ \\
\hline
\end{tabular}

Based on table 4, it can be seen that most of pregnant women at Gamping Health Center 1 mostly had good knowledge, that's 30 respondents or $66.7 \%$.

2. The relationship between parity and knowledge of pregnant women about the KIA Handbook at Gamping Health Centre 1 Yogyakarta.

Table 4. Tabulation of Cross Relationships Parity with pregnant women knowledge about KIA Handbook at Gamping Health Centre 1 Yogyakarta

\begin{tabular}{|c|c|c|c|c|c|c|c|c|}
\hline \multirow{3}{*}{ Parity } & \multicolumn{4}{|c|}{ Knowledge } & \multirow{3}{*}{ Total } & \multirow{3}{*}{$P$ value } & \multirow{3}{*}{ OR } & \multirow{3}{*}{ CI } \\
\hline & \multicolumn{2}{|c|}{ Moderate } & \multicolumn{2}{|c|}{ Well } & & & & \\
\hline & $\mathbf{F}$ & $\%$ & $\mathbf{F}$ & $\%$ & & & & \\
\hline Primigravida & 12 & $48.0 \%$ & 13 & $52.0 \%$ & 25 & 0.020 & 5.23 & $1.21-22.4$ \\
\hline Multigravida & 3 & $15.0 \%$ & 17 & $85.0 \%$ & 20 & & & \\
\hline
\end{tabular}

Based on table 4, of the Chi Squere test results, it shows that the p-value is 0.020. Therefore, the p-value $>\alpha(0.05)$ means that there is a relationship between parity and pregnant women knowledge on KIA Handbook at the Gamping Health Centre 1 in Yogyakarta.

Description of Parity in Pregnant Women at Gamping Health Center 1. The results showed that most of the pregnant women at Gamping I Health Center were mostly primigravidas, namely 25 respondents or $55.6 \%$. Parity is the number of live births a woman has (Cunningham, 2012). Parity is the number of children born to the mother, both alive and dead. Parity of a mother is not safe to get pregnant and give birth is in the first pregnancy and high parity (more than 3), parity 2-3 is the safest parity in terms of maternal mortality (Fitriana, 2009).

Based on the above definitions of parity, it can be concluded that parity is the number of births or live births experienced by a mother. Parity is the status of a woman in relation to the number of children she has been born with. Parity is a woman who has given birth to a viable baby. (Puji E, et al. 2007). Parity is one of the factors that affect the knowledge of mothers, mothers with parity or who have just experienced pregnancy for the first time have different knowledge from mothers who have been pregnant more than one time this is in accordance with Notoatmodjo's theory (2017) that one of the factors that affect knowledge is experience.

Description of Knowledge on Pregnant Women at Gamping Health Center 1 Based on the study results, it was found that most of pregnant women at the Gamping Health Center 1 had good knowledge, namely 30 respondents or $66.7 \%$. Knowledge is the result of knowing and this occurs after a person senses a certain object. The sensing of the object occurs through the five human senses, namely sight, hearing, smell, taste and touch by itself. When sensing produces knowledge, it is influenced by the intensity of attention and perception of the object (Wawan \& Dewi, 2011). The level of cognitive knowledge is very important for the formation of one's actions. From experience and 
research, it turns out that behavior based on knowledge will be more lasting than behavior that is not based on knowledge.

Maternal mortality can occur during pregnancy, during childbirth and during puerperium due to a lack of knowledge to recognize the danger signs that are experienced such as excessive nausea, vomiting, bleeding, premature rupture of membranes, fever, swelling of the hands and even the face with blood pressure, height and reduced fetal movement. Knowledge regarding danger signs during pregnancy is important for pregnant women to know so that they can ask for help or assistance as soon as possible when they encounter these danger signs. Ignorance of this causes delays in dealing with danger signs in pregnancy that will seriously endanger the lives of both the mother and the fetus. In reducing MMR, the government has issued several programs and efforts, which is Maternal and Child Health Book program or KIA Handbook which has been piloted since 1994 (Depkes, 2013). Good knowledge of the benefits of the KIA handbook will encourage mothers to read and use the KIA handbook so that mothers can be more aware of the danger signs of their pregnancy, etc., so that it is hoped that it can reduce the incidence of pregnancy complications which in turn can reduce the maternal mortality rate.

The relationship between parity and knowledge of pregnant women on the KIA Handbook. The results of the research in table 4.3 show that the Chi Square test results show that the $\mathrm{p}$-value is 0.020 . Therefore, the $\mathrm{p}$-value $>\alpha(0.05)$ means that there is a relationship between parity and the knowledge of pregnant women on the KIA Handbook at the Gamping Health Center 1 in Yogyakarta. The KIA book is the result of collaboration between the Ministry of Defense and the Japan International Cooperation Agency (JICA) as one of the government's efforts to reduce MMR. The KIA Handbook is a simple and effective information, education and communication tool (Destria, 2010). Based on the third competency, midwives have the authority to provide comprehensive antenatal midwifery care to optimize health during pregnancy which includes early detection, treatment or referral of certain complications (Mufdlilah, et al, 2012).

The Maternal and Child Health Book (KIA) is given to all pregnant women in order to increase the knowledge and understanding about maternal and child health. Besides being a health record for pregnant women and children, the KIA Handbook is also a tool that can be used to periodically control maternal health and a means of communication between health workers and patients. Factors that caused mothers to not use the KIA handbook optimally were the mother's level of knowledge about the KIA handbook. Knowledge is a very important domain for the formation of one's actions (overt behavior). Mothers who have high knowledge and are aware of the importance of the KIA BOOK will continue to use and read the KIA book as a guide in carrying out examinations during pregnancy (Eni Kurniawati, Ari Sulistyawati, 2013).

From this study results, it appears that pregnant women with the multi gravid category have a better level of knowledge; this is because mothers who already have children have more experience than their first child. In terms of experience in childbirth, it can be interpreted that mothers who have parity or more than one number of children will have a lot of experience about their pregnancy directly, so that the mother knows more or less and has used the KIA book more than once so that the mother's knowledge is calm. KIA is increasing. This is in accordance with Notoatmodjo theory (2007). 


\section{CONCLUSION}

Chi Square test results show that the p-value is 0.020 . Therefore, the $p$-value $>\alpha(0.05)$ means that there is a relationship between parity and the knowledge of pregnant women on KIA Handbook at Gamping Health Center 1 in Yogyakarta.

\section{REFERENCES}

Damanik, RL (2009). Hubungan Karakteristik, Pengetahuan dan Sikap Ibu Hamil dengan Pemeriksaan Haemoglobin Sewaktu Hamil di Puskesmas Darussalam Kecamatan Medan Petisah tahun 2008. Publication manuscript. Public Health Faculty, North Sumatra University, Medan.

Eni Kurniawati, Ari Sulistyawati. (2013). Pemanfaatan Buku Kesehatan Ibu dan Anak Oleh Ibu Hamil Trimester III. Jurnal Ilmu Kebidanan, Volume I, Number 3, December 2013.

DIY Health Office. (2017). Profil kesehatan tahun 2015 kota Yogyakarta. Yogyakarta:Health Office.

Mufdlilah, et al. (2012).Konsep Kebidanan. Yogyakarta: Nuha Medika.

Notoatmodjo. (2010). Metodologi Penelitian Kesehatan. Jakarta: Rineka Cipta.

Wawan, A \& M, Dewi. (2011). Teori dan Pengukuran Pengetahuan, Sikap dan Perilaku Manusia. Jakarta: Nuha Medika. 